\title{
DEVELOPMENT OF CRITICAL THINKING IN EDUCATION OF LATVIA: SITUATION ANALYSIS AND OPTIMISATION STRATEGY
}

\author{
Zanda Rubene \\ University of Latvia, Latvia \\ Artis Svece \\ University of Latvia, Latvia
}

\begin{abstract}
The aim of this study is to analyze the experience of developing critical thinking in schools and higher education institutions of Latvia within the last 20 years. It should be emphasized that 2018 marks the $20^{\text {th }}$ anniversary since the project to develop critical thinking approach in the education of Latvia was started. That is a significant reason to look back and also to evaluate critically the progress made in this area.

Even though critical thinking has been important for the educational practice in Latvia since mid-90ties of the $20^{\text {th }}$ century, it is still a subject of heated debate. As a Post-Soviet state, Latvia joined the critical thinking promotion movement in 1998 with a view to advance a more rapid formation of a democratic consciousness in the society. Education was perceived as a means to socially transform (i.e., democratize) the society. But the study "On the use of the critical thinking development approach in educational system: its impact and effectiveness in Latvia" that was done ten years later, in 2008, demonstrated that no significant changes had taken place in the education system of Latvia in those ten years. The social studies of recent years even suggest that the society of Latvia is becoming more radicalized. The same processes could be at work in another area of education development, one can observe difficulties with understanding and promoting media literacy in the context of the society of Latvia becoming digitalized.

This study analyzes the reasons behind the current state of affairs and suggest some ways forward. Notwithstanding the polarization of opinion, critical thinking in Latvia is still considered to be a means to reach participatory democracy and create a democratic model of education.
\end{abstract}

Keywords: critical thinking, critical thinking approach in education, a democratic model of education. 


\section{Introduction}

Freedom, responsibility and tolerance are considered to be values that are particularly significant for a democratic society; however, ensuring these values is one of the most difficult tasks for the democratic society. Safety that is rooted in freedom, not the restriction of freedom, is a vital condition of this society. This means that a member of a democratic society has to develop such personal qualities that would give a possibility to be aware of and cultivate the critical understanding of one's freedom and at the same time to understand and respect the other person's rights to it. Thus, one of the key objectives of modern education is to promote the development of such a society the representatives of which value highly every person's ability to be free, tolerant and critically thinking. They should respect every person as an individuality but also be aware of the belonging and involvement as personally meaningful values that include both the social, universal, and ecological dimension. This process should start with the individual's self-awareness, self-reflection and selfcriticism (Rubene, 2008).

The dynamic development of the society incites the education to react to the social and cultural novelties, reorganizing continually and seeking adequate solutions to the challenges of the age. The traditional understanding of education as passing the knowledge and principles of one generation to the next is replaced by a new one the aim of which is to prepare new generations for the life in the future society emphasizing the necessity to activate pupils and students' thinking potential, to develop independent inquiry skills for solving the tasks presented by the changing social environment and global challenges.

One of the most important factors in today's social transformations is the development of information technologies. It influences the demand for critical thinking skills for two reasons at least. First, information technologies change considerably the situation in the labour market and understanding of the concept of work. This, in turn, means that in future more than today the employees, professionals and creators of their own jobs will need the skills that will allow them to adjust dynamically to the rapid changes in the social, economic, business and technology environment (Schwab, 2016). Critical thinking is one of such skills. For instance, the European Council mentions it as a vital part of several key competences (literacy, digital entrepreneurship) that a person needs to be able to join successfully the labour market (Council of the European Union, 2018).

Secondly, the development of information technologies increases rapidly the amount, diversity and quality of the information accessible in the public space. The way we communicate, perceive and analyse 
information changes (Eriksen, 2001). The dissemination of "fake news", trends of manipulated populism in several Western democracies, as well as the success of state-organized cross-border propaganda give cause for concern about the capacity of critical thinking to influence society and the possible threats that result from the impoverishment of the judgment. Nowadays it is difficult to evaluate information; there is a possibility to manipulate with it easily, and it evidently exerts impact on the public opinion and the quality of the public discussion (Rifkins, 2004; McIntyre, 2018). Still, critical thinking as a means for developing independent thinking is considered by many to be a solution to these problems.

One should not forget another reason why the inability to evaluate the information critically and to form a qualitative discussion is dangerous to democratic societies. Since Enlightenment critical thinking has been considered an important means to avoid violent conflicts. Critical thinking is not just about the ability to evaluate information, it is also a tradition essential for democracy in which conflicts are solved through a reasoned discussion. If there is no discussion and consensus at the end of the discussion then the quarrel has to be solved with the help of violence.

Accordingly, if these assumptions are correct then the inability to listen to arguments, the lack of any tolerance towards another opinion, the inability to reach the decision in the discussion that is acceptable to all parties, even if not perfect, can turn out to be a way to the society in which violent conflicts become commonplace. It does not mean that the critical thinking tradition is untouched by power relations and does not have its normalization aspects. Therefore, in the end the question about critical thinking is the question about the society we want to live in, and correspondingly, how do we imagine the future of the world, Europe and Latvia.

Thus the question about the forms and methods in education that help to develop the learner's skills to analyse and assess the diverse social processes becomes crucial. Respectively, the skills of independent learning and formation of judgments in modern social sciences are considered one of the most significant means for the person's self-realization in society.

Not only pedagogues, but also sociologists, philosophers, anthropologists, psychologists and political scientists have joined the discussion about the conception of the future education and upbringing. Representatives of different social sciences and humanities are preoccupied with the social identity problem, the problem of stereotypical thinking, and the issue of accepting the difference. Thus, the clarification of pedagogical possibilities of improving critical thinking becomes one of the topical problems in modern education.

Although the method of forming critical judgments has been seriously analysed and explored since the $18^{\text {th }}$ century in European scientific thought, 
debates still continue, and also in the in pedagogical discourse of Latvia, the concept of critical thinking has raised discussions (Rubene, 2008; Rubene, Svece, 2018). There is a part of the society in Latvia which is close to the science and practice of pedagogy and supports the introduction of critical thinking approach in schools and universities. There are also those who consider the pedagogical model related to this theory to be imported from America and assess rather sceptically its adaptation possibilities in Latvia. Both groups are participating in these discussions. However, despite the polarization of opinions, critical thinking has been a well-known phenomenon in Latvia since 90ies of the $20^{\text {th }}$ century.

Yet, it has to be admitted that in 20 years, on the one hand, critical thinking as a phenomenon of education has become known and accustomed in Latvia, on the other hand - effective development of critical thinking is still considered problematic in the education of Latvia.

\section{Idea of critical thinking in the education discourse in the $20^{\text {th }}$ century}

Critical thinking in the context of education is explained as understanding of good thinking, as a pedagogical approach, or a set of teaching and learning strategies the aim of which is to promote independent thinking, considering it as the opposite to mechanical memorization, repetition, application of rigid models. Critical thinking is explained also as a method for making meaningful and responsible decisions both in teaching/learning and social spheres (Rubene, 2016).

The critical thinking phenomenon in the context of education has developed in two relatively independent directions - one of them implements the development of critical thinking directly, i.e., as a separate school subject, the other - indirectly, i.e., as a transversal skill of the whole teaching/learning process (Klafki, 1998; McPeck, 1981; Rubene, 2008).

The direct approach of developing critical thinking emerged in the USA where it has been considered a serious part of pedagogical theory and practice since the 70 ies of the $20^{\text {th }}$ century. In the 80ies of the $20^{\text {th }}$ century, the critically reflective paradigm of education that envisaged the inclusion of critical thinking as a subject in the teaching/learning content was already considered a point of reference for the education system reforms in the USA (Kincheloe, 2000; McPeck, 1981; Rubene, 2008). Critical thinking in the pedagogical practice of the USA is known as the movement of informal logic and critical thinking, the key driving force of which is the demand for general judgment skills, and the task of which is to improve the judgment, argumentation, critical analysis and debating skills with the help of methods specifically developed for this purpose. Thus, the basis 
of research interest is the development of pedagogical conditions and tools for purposeful and effective development of learners' logical thinking skills (Ennis, 1996; McPeck, 1981).

Critical thinking in this approach is understood as a rational action of individual consciousness that possesses the ability to identify and reflect on one's thinking process and that is necessary for productive functioning in the society. Robert Ennis, Richard Paul, Mathew Lipmann a. o. are named as the leading representatives of the direct critical thinking approach in education (Ennis, 1996; McPeck, 1981; Paul, 1990).

The direct critical thinking movement in education has created several fundamental conceptual questions in its development, e.g., whether the direct development of critical thinking in school really brings the desired outcomes - it is possible, it is better to teach the reasoning skills indirectly in the process of studying philosophy, mathematics, or classical languages (Hinkkanen, 2000; Kincheloe, 2000; Paul, 1990). The acquisition of critical thinking as a separate school subject has also incited the discussion that is connected with the opinion that every branch of science presupposes a specific way of reasoning therefore it is possible to learn it only within the framework of this science.

It has to be admitted that the above mentioned discussions are rather wellgrounded. Reducing critical thinking to the logically argumentative aspect and understanding it as a reflection on the cognitive process, the aspect of "criticism" in critical thinking is curtailed and understood very narrowly. This discussion continues also in the pedagogical discourse of Latvia, especially concerning the use of the critical thinking concept in the accepted sense of pragmatism pedagogy - automatic, non-reflected transfer of concepts from one tradition to the other is criticized. The discussion about the use of the concept "critical thinking" in the education of Latvia is commendable not just because critical evaluation of concepts is the requirement of the critical judgment method but also because it promotes research in this sphere.

In the education research of the turn of the $20^{\text {th }}$ and $21^{\text {st }}$ centuries, critical thinking is called formal when it is reduced to the development of formal analysis and argumentation skills or culture-neutral critical thinking. Emphasizing the idea about the acquisition of effective strategies and techniques as a means of developing critical thinking, the development of critical thinking in school is often reduced to the acquisition of teaching/ learning methods - learners train isolated cognitive skills and receive assessment but they do not apply them in their everyday life. It is claimed that the main mistake of the programme as it was introduced in education system is the loss of the idea of total integrity of critical thinking, dividing it in concrete skills. The assumption that parts joined together will equal the whole has turned out to be a hasty one. It has to be admitted that in 
this case the whole is much broader and more complicated than simply the sum of the parts (Hinkkanen, 2000; Kincheloe, 2000).

Critical thinking in this approach is being hyper-rationalized, reduced to the totality of cognitive skills that facilitates instrumental knowledge but tries to distance itself from political and ethical dimensions. Critical thinking thus loses its reflective character in its broader sense and becomes disinterested because it is perceived as a cognitive process which takes place in vacuum. The fact that critical thinking always requires personal transformation is forgotten. Students are taught to differentiate, to group, to divide in categories, to distinguish essential information from irrelevant, to draw conclusions, to justify claims, etc. while staying in the boundaries of formal thinking, learning a fragmented and simplified version of scientific thinking (Hinkkanen, 2000; Kincheloe, 2000, Rubene, 2008).

The second approach which develops critical thinking as a transversal skill in the whole teaching/learning content has been formed in the context of critical pedagogy, which emphasizes the independent, emancipating advancement of critical self-reflection for the development of democratic society. Such concepts as critical judgment, learning, emancipation, autonomy, judiciousness should become the leading motive in today's democratic society in which people can influence the social conditions and to use them rationally (Klafki, 1998; Kron, 1999). The aim of critical pedagogy is to develop critical thinking as a transversal skill, i.e., to promote social transformations with the help of sensibly thinking individuals. Critical pedagogy, too, announced itself in the 70ies of the $20^{\text {th }}$ century; its most significant representatives are Wolfgang Klafki, Paulo Freire and others.

A specifically elaborated teaching/learning methodology is less characteristic to critical pedagogy; it emphasizes more a particular view for explaining the localization of social problems with the help of judicious action, emancipation and self-determination. The person's independence and self-determination has to be developed through education, the individual education process is treated as a socially conditioned process. The objective of the pedagogical action is to give a formation possibility for the individual who is ready for democratization, emancipation, mental maturity and selfdetermination (Klafki, 1998; Rubene, 2016). The criticism of ideology in critical pedagogy is looked upon as a teaching/learning method for shaping the sense of common responsibility, for finding out and preventing the risks that threaten democracy.

The approach that critical pedagogy has chosen for developing critical thinking in education has also provoked discussions. Representatives of critical pedagogy are criticized for the lack of precise methodological instructions that improve critical thinking. Also, the very idea of emancipatory pedagogy - the possibilities to form an individual who is 
completely free and who is not connected with his social and cultural historical situation - is being questioned (Kincheloe, 2000; Rubene, 2016). Namely, time and space restricts the individual, thus also his potential possibilities are restricted. It is connected with the social political experience and memory of Europe - the historically acquired prudence makes us doubt the belief in the unlimitedness of human thinking abilities. Thus, the very idea of a critically thinking personality is being problematized.

However, it has to be admitted that in the context of society's digitalization one can hear more often an opinion that indirect development of critical thinking, e.g., its acquisition synthesizing critical thinking and media literacy, has to be considered the most optimal pedagogical strategy (Rubene, Svece, 2018).

The development of critical thinking in the education system of Latvia has been rather unique - there have been attempts to implement both direct and indirect approach of developing critical thinking in the school and university practice. Unfortunately, the situation in the field of developing critical thinking in the education of Latvia can also be described as unsystematic, untargeted and fragmentary.

\section{Critical thinking in general comprehensive education in Latvia}

In 2018, the approach of developing critical thinking celebrated 20 years in Latvia. In 1998, the program "Transformation in Education" was launched with the support of Open Society Institute and Soros Foundation in Latvia and the ambitious movement to develop critical thinking was initiated. The movement focused on promoting the critical thinking skills of school teachers and academic staff of higher education institutions. Numerous further education courses were organized, several textbooks were published, and the idea of developing critical thinking was integrated into education standards of Latvia.

It is necessary to emphasize the fact that all of this happened shortly after the collapse of the Soviet Union in 1991. The purpose of developing critical thinking in education in the 90ies of $20^{\text {th }}$ century was a necessity to accelerate the development of democratic consciousness in society more rapidly, considering education as a means of social transformation of the society - a means of democratization. In the post-Soviet society there was a lack of ideas and skills relevant to democracy - such as argumentation skills, civic participation, openness to diversity, etc. Therefore, the development of critical thinking in Latvia should have become an important milestone for the transformation of public opinion. Naturally, there emerges a question whether the disposition of critical thinking has overall increased in education and society? 
The non-governmental organisation "Education Development centre" (EDC), which is considered the most significant implementer of critical thinking development programmes in Latvia, in cooperation with International Reading Association and Reading and Writing for Critical Thinking International Consortium, RWCT IC during the time period from 2004 till 2017 has organized further education courses and professional development of teachers and other educationalists in Latvia in the field of developing critical thinking. EDC data show that 13414 teachers and education-related specialists have finished such professional development courses (EDC, 2018). EDC has acted as the deliverer of courses for developing critical thinking skills, has contributed to the improvement of knowledge and skills of university academic staff and other educationalists, has initiated discussions about the promotion of the critical thinking approach for university academic staff, education policy makers, education leaders and society representatives.

However, on the whole the results of education research allow us to conclude that the development of critical thinking in education in Latvia has not reached the aims intended by the implementers of this idea (Baltic Institute of Social Sciences, 2008; ICCS, 2016).

In 2008, the Education Development centre together with Baltic Institute of Social Sciences performed a study "On the use of the critical thinking development approach in educational system: its impact and effectiveness in Latvia". The aim of the research was to explore the impact and effectiveness of critical thinking in education system and to gain understanding and evaluation of the involved target groups within the period of 10 years. This research served for the society of Latvia as a summary and reflection on the development within critical thinking in the context of education.

Although the study marked many benefits gained from the implementation of the critical thinking approach in the education of Latvia, e.g., students had developed a number of skills necessary for learning (the skill to select and structure information, to work in a group, to cooperate, etc.), this approach had made the teaching/learning process more interesting and attractive as well as positive changes were observed in the mutual interaction models of teachers and pupils, the study still did not show considerable changes in the improvement of critical thinking in the education system on the whole (Baltic Institute of Social Sciences, 2008).

It was concluded that the requirements to develop learners' critical thinking skills appear only fragmentarily in the education policy documents of Latvia. One of the main reasons for such a conclusion was the fact that teachers used the critical thinking approach in schools based on the notion that this approach is a combination of various interactive teaching methods. Teachers lacked conceptual understanding of the approach of 
critical thinking from the perspective of philosophy of education; therefore, they were largely unaware of the impact of these methods in the social sphere. Teachers admitted that they also had difficulty changing their usual working style. As a result, they used the new methods to work "as usual" (Baltic Institute of Social Sciences, 2008).

As a problem in implementing the critical thinking development approach was mentioned not only teachers' insufficient readiness to adopt this approach, but also the parents' attitude. For parents, it seemed more important to have children receiving a certain amount of knowledge at school rather than the ability to analyse and evaluate this knowledge. Therefore, they considered the development of critical thinking insignificant.

Overall the authors of the research came to the conclusion that by improving the models of teachers education, by eliminating fragmentation in education practice, and also by anticipating conceptual changes in of the study process, growth of effectiveness of the critical thinking approach are expected (Baltic Institute of Social Sciences, 2008).

In the last 10 years the relevance of critical thinking to the society of Latvia has only grown - it has social and political, local and global causes. Developing critical thinking in the context of digitalization of the society has gained a new context - it is named as a component of contemporary media literacy (Spurava, 2018). All the above mentioned also resonates in the field of education - the work on promoting critical thinking has continued among students, in teacher education and professional development. However, has the situation changed substantially?

Latvia has joined the International civic and citizenship education study (ICCS), which assesses comparatively in time and space pupils' civic knowledge, civic attitudes, their understanding of participation and involvement. The aim of ICCS is to evaluate the readiness of the young people in the participating countries to take civic roles that are characteristic to the second decade of the $21^{\text {st }}$ century. This study involves the evaluation of the students' critical thinking skill. In 2016, the results of the International civic and citizenship education study showed that the achievement of Latvia's pupils in the field of civic education were lower than the European average. It was concluded that the teaching/learning process, which was implemented in the field of civic and citizenship education in Latvia was a non-efficient process and this explained the low achievement.

The results of the survey carried out in the study showed that teachers in Latvia had a theoretical knowledge about the significance of the critical thinking skill $-65 \%$ of teachers (ICCS 2016 average is 61\%) mentioned in the survey the promotion of critical and independent thinking as one of the most important aims of the civic education. However, the achievement 
of their pupils did not demonstrate a high level of critical thinking. It leads to the conclusion that teachers know what critical thinking is and are aware of its necessity but cannot apply this knowledge in practice for promoting their pupils' critical thinking (ICCS, 2016).

The recent education reforms have given hope to those involved in the education system that the improvement of critical thinking in the education of Latvia has obtained a systemic outline.

In 2018, the National Centre for Education of Latvia in the project "School 2030" worked out and on November 21, the Council of Ministers of the Republic of Latvia approved the compulsory teaching/learning content for preschool (preschool guidelines) and on November 27 - for basic education (standard (Regulations of the CoM, Republic of Latvia LR Nr. 716, Regulations of the CoM, Republic of Latvia Nr. 747, 2018). In 2019, the standard of secondary education has been submitted for approval in the Council of Ministers of the Republic of Latvia. Specific learning outcomes for the development of critical thinking as a transversal skill have been defined in all the above mentioned documents.

At the beginning of 2018, in the framework of "School 2030" the new vision on the education content of Latvia "Education for modern literacy: description of the teaching/learning content and approach" the aim of which is to improve the teaching/learning approach and the content at school as well as to implement substantial changes also in teacher education and professional development has been offered for public discussion. Critical thinking has been named in the project as one of the most important transversal skills for the modern learner. Thus, constructing the vision of future education, the necessity of developing critical thinking again has been emphasized in Latvia.

The abovementioned project considers critical thinking along with self-actualization, creativity, cooperation and other skills as the necessary transversal skill that every learner needs, and that has to be present in the whole teaching/learning process and in all subjects taught in school (School, 2030).

It can be concluded that, regarding critical thinking, the project "School 2030" has taken into consideration the conclusions drawn in 2008 in the study "On the use of the critical thinking development approach in educational system: its impact and effectiveness in Latvia".

First of all, the project envisages systematic changes in the school curriculum, and they are based on the general goal of having a learner who has mastered the necessary skills, knowledge and attitudes of the $21^{\text {st }}$ century throughout the process of general education.

Secondly, by implementing a critical thinking approach in all the curriculum as a transversal skill rather than by developing it in separate 
school subjects, the fragmentation in the development of critical thinking will theoretically be eliminated.

Thirdly, the novelty of the project for Latvia is that teachers are not equipped with certain methods and techniques - they have received the goals of the activities which are critical thinking learners. Finding the most appropriate means for achieving this goal is the task of the teachers themselves. Moreover, by independently looking for solutions to achieve educational goals, teachers will also develop their critical reasoning.

Fourth, with the support of the European Structural Funds and the Ministry of Education and Science, a conceptual reform of teacher education has been launched in Latvia. It aims to create study programs that train teachers with skills and knowledge necessary for the new school curricula envisaged by the project "School 2030". Thus, the efficiency of teachers' activity is expected to increase (Rubene, Svece, 2018). The project "School 2030" offers a new model for the curriculum, but its success will depend on teachers' readiness to be actively involved in its implementation (an important indicator of democratic education).

Of course, the issue of the insufficient readiness of teachers in Latvia to implement the new curriculum has not gone away. First, not all teachers are ready to step out of their comfort zone, they want clear criteria for evaluation and clearly defined amount of knowledge that goes with that. The project "School 2030" gives much larger freedom to teachers and schools to create their own content and choose teaching methods that correspond to it, but that means also a greater responsibility and larger amounts of creative energy that has to be invested in the teaching process. For many it is a stressful position, and they look for clear and specific instructions for what to do in the classroom. Secondly, although the reform involves a complete review of the way teachers are trained on the university level and the development of new teacher training programs, this process is not directly supervised by the project "School 2030". That means there is a danger that in some areas there could appear a gap between the intentions of reformers and realities of teacher readiness for the new educational framework, including critical thinking as a transversal skill.

One should also mention occasions of negative reactions to the reform in general public. For example, in the context of discussions on the social role of the child in the family and at school, people sometime express concern about the danger of the development of critical thinking to the value system of children as it allegedly reduces obedience and respect for adults. Also, the attitude of Latvian politicians towards this project is not unambiguous either.

On the whole, it should be concluded that it is necessary to continue discussions about promoting the development of critical thinking in 
the general education system of Latvia to minimalize the stated shortcomings and deficiencies and to improve the implementation of the critical thinking approach.

\section{Critical thinking in higher education}

In order to describe the place of critical thinking in higher education, we have to return to the three meanings how this term is being used as the ideal of thinking (independent, reasoned, evaluating thinking), as the method of teaching (the lecturer trains the student's ability to judge about specific questions without teaching critical thinking as a subject) and as an academic course (the aim is to teach particular techniques of text analysis and text construction in the broadest meaning of the word "text") (Rubene, Svece, 2018).

Critical thinking as an ideal has been present in higher education since its beginnings although the understanding of what this ideal means and how it should be manifested in the study process has changed with time.

Nowadays there are at least two main reasons why critical thinking is considered important -1 ) higher education nowadays is required to ensure a link with the research, and research presupposes the skill to think independently and seek new solutions instead of repeating the acquired knowledge, 2) higher education still has not lost its social function, its task is to train people who are able to solve different problems not only the ones that have been mastered in the university study process but also new, situational, connected with different spheres of life and employment. University teachers admit that their aim is not to transfer information but to help students to become independently thinking persons and researchers (Paul et al,1997).

The fact that critical thinking ideal is highly valued in higher education does not mean that the aims of the study process are always attained and consequently we should ask how critical thinking as a teaching/learning methodology or critical thinking as a study course can help to reach these aims. It is not that a person who does not know the methodology of critical thinking cannot teach students independent thinking or that a student who has not had a critical thinking course is unable to think critically. Independent, critical and reasoned thinking is a general feature of human thinking and we can use it, in a way, intuitively. However, there is no doubt that our rationality is limited and intuition is not always effective enough.

Although the presence of critical thinking has been marked since 2008 both on the European and national levels in the Qualifications Framework for higher education (EQF, 2018), the understanding of the critical thinking methodology among the academic staff of higher education institutions in 
Latvia, certainly, is not sufficient. Accordingly, one cannot claim it is used systematically in the study process. It means that the study process in higher education would certainly benefit if the skills to apply this methodology were trained and the academic staff had a clear notion what they were and how to use them in the teaching of particular areas of studies. The question is how to achieve it. It is hardly possible that the desired way would be compulsory requirements. It has to be taken into account that both learning of methodology and its introduction into the delivery of a concrete course requires enormous time and other resources. First of all, a convincing offer should be ensured - courses in the form of modules that the academic staff could master and in which there is clearly formulated benefit from such courses.

Critical thinking as a methodology has no limits; it could be applied to any branch of science and approbated for the particular needs. Critical thinking as a course that is offered to students and academic staff in several higher education institutions of Latvia, in a way, has a narrower application (Kincheloe, 2000). Although in principle it is possible to design a course, say, about, critical analysis of research texts in chemistry, such a course in the end would overlap with the methodology issues of the particular science in question. Another point is that also the methodology of science can be analysed on different levels and students would definitely need to acquire the most general level which analyses the general assumptions of the science. Critical analysis of science on this level basically becomes the philosophy of science.

Critical thinking as a course functions the most effectively as a general analysis of thoughts, statements and texts and corresponds to those skills that are necessary for any person who writes something, participates in a discussion and thinks about what the others have said. As a course critical thinking has developed historically as the analysis of argumentation and combines the elements of informal logic and rhetoric. Such courses are very rare in the higher education institutions of Latvia. Most likely, there are different reasons for that, one of them - such courses are dedicated to general competences, and do not focus on issues of one particular science that the university programme is meant to teach. This, certainly, belongs more to the domain of humanities and social sciences although science communication is one of the most important parts of the researcher's work today, and that makes critical thinking a subject essential also for them. Still, as it was said before, the course is almost never included in the study programmes either in the social sciences or natural sciences.

The presence of such courses in the university programmes would be recommended, yet it has to be taken into account that understanding about what critical thinking course should be also has to be reconsidered. When in 1970ies, critical thinking courses appeared in the USA they were focused 
on the analysis of argumentation (Rubene, 2008). However, argumentation is not the only thing that is important for people's discussions and texts. Taking into consideration discussions about the perception of information in different media and ways of manipulating with the message, critical thinking should more incorporate themes related to rhetoric and media literacy.

Finally, the attention should be paid to the fact that at present one can notice conflicting and almost contradictory conceptions of what are the aims of higher education. The aim to link higher education to scientific research can get into a conflict with general educational aims of higher education; at the same time, focusing on research and the development of the person's general capacity to reason as the aims of higher education can contradict the society's demand for practicality and applicability in higher education.

This conflict is not absolute and often is rooted in misunderstandings; yet critical thinking as a method and as a course can help to connect these aims although it means also careful evaluation of aims and practices of critical thinking.

\section{Conclusions: recommendations for improving the development of critical thinking in the education of Latvia}

In order to analyse the situation in the development of critical thinking in education in Latvia, an experts' discussion was organized on August 22, 2018 in the House of European Union in Latvia "Development of critical thinking in education in Latvia". Education experts, academics, school heads and teachers as well as representatives of European Commission Agency in Latvia participated in the discussion. The discussion resulted in formulating recommendations for improving the development of critical thinking in education in Latvia.

\section{On the state level:}

- It is necessary to carry out a representative research about critical thinking skills in the society and the society's attitude towards critical thinking and its concrete aspects. The research should mark a broader social, cultural and value context that critical thinking has in Latvia, including the evaluation of out-of-school/university factors that influence the work and attitude of school and university teachers to critical thinking. It would be interesting to learn the level of critical thinking of "opinion leaders", e.g., politicians.

- Critical thinking has to be developed not only to avoid manipulations in media but also to decrease the possibility of violence, thus it is also a question of safety. At present, critical thinking is often focused on independent evaluation of information, exploration of fake news, 
winning debates but more has to be done to work out methodology for schools and higher education that would allow to develop the culture of evolving a shared opinion, communication, making a common decision and discussions.

- To expand information campaigns about the necessity and importance of critical thinking in the society, emphasizing the content of critical thinking and its nuances, not the critical thinking phenomenon as such. The popularization of critical thinking should include the explanatory aspect, stressing critical thinking not only as a technical skill but also as an essential element in self-formation of a person and society, the connection of critical thinking with human and democratic values, as well as emphasizing critical thinking and reasoned discussion as a means of finding shared opinion, not as the practice of quarrelling and its legitimization.

In the education system:

- Clear criteria should be worked out for assessing the quality and development of critical thinking in the education system. Based on these criteria, it is necessary to perform a representative research about the situation regarding critical thinking in schools and higher education institutions in Latvia in order to formulate the necessary improvement mechanisms.

- A complex analysis of competence-based teaching/learning process is necessary for evaluating how concrete critical thinking skills are worked into and used in the teaching/learning process, especially paying attention to the contribution of different school subjects to the development of critical thinking competence, in order to avoid the situation that the teachers of subjects work on transferring knowledge relevant for their subject assuming that other teachers take care of critical thinking.

- Analysing the benefits and drawbacks from using different critical thinking strategies in the teaching/learning process, also comparing the direct and indirect approach in the development of critical thinking, to elaborate recommendations for teachers of different subject.

- To work out recommendations on how to ensure cooperation among teachers and/or university academic staff that considerably improves the possibilities to work critical thinking principles and methods into the teaching/learning process.

- To develop the understanding about the importance of group and project works in schools and higher education institutions. Cooperation as one of the key words that should help teachers to expand simultaneously the presence of critical thinking in school curriculum and teaching process. 
- It is necessary to develop purposefully the transversal skills in teacher education: critical thinking, logic, presentation skills, academic reading and writing, media literacy, civic education and ethics.

- To find a possibility in further education of teachers to organize courses on improving critical argumentation skills which will bridge the gap between teacher's knowledge about critical thinking and their own skills in this field.

- To allow children the possibilities of choice already at the preschool level thus developing their decision making ability and the ability to explain and justify their standpoint.

- To develop methods and recommendations about cultivating and popularizing critical thinking in the out-of-school organized learning process, paying special attention to the possibilities given by student research work at school, etc.

\section{References}

Baltic Institute of Social Sciences (2008) Kritiskās domāšanas attistǐšanas pieejas izmantošana izglïtibas sistēmā - ietekme un efektivitāte Latvijā. [On the use of the critical thinking development approach in educational system: its impact and effectiveness in Latvia]. http://www.iac.edu.lv/assets/Publications/Kritiska-domasana-web.pdf.

Dominguez, Caroline (coord.). A European Collection of the Critical Thinking Skills and Dispositions Needed in Different Professional Fields for the $21^{\text {st }}$ Century, Vila Real, Portugal: UTAD, 2018. http://bit.ly/CRITHINKEDUO1.

Dominguez, Caroline (coord.). A European Review on Critical Thinking Educational Practices in Higher Education Institutions, Vila Real: UTAD, 2018. http://bit.ly/CRITHINKEDUO2.

Eiropas Savienības Padome (2018) Padomes ieteikums par pamatkompetencēm mūžizglìtïbā. [ Council of the European Union. Recommendation on key competences for lifelong learning]. https://eur-lex.europa.eu/legal-content/LV/TXT/PDF/?uri=CELEX:32018H0 604(01)\&from $=$ EN.

Ennis, R. H. (1996) Critical Thinking.Upper Saddle River, NJ.: Prentice Hall.

Eriksen, T. H. (2001) Tyranny of the Moment: Fast and Slow Time in the Information Age. London: Pluto Press.

European Commision. (2018) Descriptors defining levels in the European Qualifications Framework (EQF) https://ec.europa.eu/ploteus/en/content/descriptors-page.

$E U$ cooperation on strengthening media literacy and critical thinking in education and training.https://ec.europa.eu/commission/commissioners/2014-2019/navracsics/ announcements/eu-cooperation-strengthening-media-literacy-and-critical-thinkingeducation-and-training_en.

Hinkkanen, H. (2000) Critical Thinking as the Objective of Anglo-American Educational Discourse. // Inquiry. Critical Thinking Across the Disciplines. Summer, Vol. XIX, No. 4, pp. 7-21.

International civic and citizenship education study 2016. HTTPS://ICCS.IEA.NL/HOME. HTML.

Izglitibas attistibas centrs. [Education Development Center]. http://www.iac.edu.lv/. 
Kincheloe, J. L. (2000) Making Critical Thinking Critical. Perspectives in Critical Thinking: Essays by Teachers in Theory and Practice. New York: Peter Lang Publishing, pp. 23-40.

Klafki, W. (1998) Grundzüge kritisch-konstruktiver Erziehungswissenschaft. Marburg. http://archiv.ub.uni-marburg.de/sonst/1998/0003/k04.html.

Kron, F. W. (1999) Wissenschaftstheorie für Pädagogen. München, Basel: Ernst Reinhardt Verlag.

Latvijas kvalifikāciju ietvarstruktūra.[Qualifications Framework of Latvia]. http://www. nki-latvija.lv/par-eki.

McIntyre, L. (2018) Post-Truth. Cambridge, Mass.: The MIT Press.

McPeck, John, E. (1981) Critical Thinking and Education. New York: St. Martin's Press.

Noteikumi par valsts pamatizglitibas vadlinijām un pamatizglitibas programmu paraugiem. [Provisions on national basic education guidelines and basic education programs]. LR MK noteikumi Nr. 747, 2018. gada 27. novembrī. https://likumi.lv/ta/id/303768.

Noteikumi par valsts pirmsskolas izglitibas vadlinijām un pirmsskolas izglitibas programmu paraugiem. [Provisions for national preschool education guidelines and examples of pre-school education programs]. LR MK noteikumi Nr. 716, 2018. gada 21. novembrī. https://likumi.lv/ta/id/303371-noteikumi-par-valsts-pirmsskolas-izglitibas-vadlinijamun-pirmsskolas-izglitibas-programmu-paraugiem.

OECD [Organization for Economic Cooperation and Development] Centre for Educational Research and Innovation. Fostering and Assessing Students' Creative and Critical Thinking Skills in Higher Education, Paris: OECD, 2018. http://www.oecd.org/education/ ceri/Fostering-and-assessing-students-creative-and-critical-thinking-skills-in-highereducation.pdf

Paul, R. (1990) McPeck's Mistakes. // Teaching Critical Thinking. Dialogue and Dialectic. New York, London: Routledge, pp. 103-123.

Paul, R., Elder, L., Bartell, T. (1997) Study of 38 public universities and 28 private universities to determine faculty emphasis on critical thinking in instruction. http://www. criticalthinking.org/pages/study-of-38-public-universities-and-28-private-universities-todetermine-faculty-emphasis-on-critical-thinking-in-instruction/598

Rifkins, J.(2004) Jaunās ekonomikas laikmets. [The new era of economics] Rìga: Jumava.

Rubene, Z. (2016) Critical Thinking in Adult Education: some reflections from the point of view of philosophy of education. In: Ricerche Pedagogiche, N 199 (Aprile/Giugno, 2016), p. 13-22.

Rubene, Z. (2008) Kritiskā domāšana studiju procesā. [Critical Thinking in the Study Process]. Rīga: LU Akadēmiskais apgāds.

Rubene Z., Svece, A. (2018). Kritiskās domāšanas attistī̌sana izglītibā Latvijāa: situācijas analize ,un pilnveides perspektivas. [Development of the Critical Thinking in Education in Latvia: Analysis of the Situation and Perspectives for Improvement]. Kūle, M. (red.) Kritiskā domāšana. Izglītība. Spriestspēja. Rīga, LU FSI, 13.-23. lpp.

Schwab, K. (2016) The Fourth Industrial Revolution. - Cologny: World Economic Forum.

Skola 2030. (2018) [ School 2030]. https://www.skola2030.lv/.

Spurava, G. (2018). Medijpratība un kritiskā domāšana. Mūsdienu aktualitātes. [Media Literacy and Critical Thinking. Current Situation.] Kūle, M. (red.) Kritiskā domāšana. Izglïtiba. Spriestspēja. Rīga, LU FSI, 25.-31. lpp. 